\title{
Penerapan Balanced Scorecard Sebagai Pengukuran Kinerja Perusahaan (PT. Gde Kadek Brothers Layar Antarnusa-Bounty Cruises)
}

\author{
Ida Ayu Putu Rika Maharani ${ }^{1}$ \\ I.G.A.N Budiasih ${ }^{2}$ \\ ${ }^{1}$ Fakultas Ekonomi dan Bisnis Universitas Udayana (Unud), Bali, Indonesia \\ email: rikamaharani123@gmail.com/Telp.0819365462728 \\ ${ }^{2}$ Fakultas Ekonomi dan Bisnis Universitas Udayana (Unud), Bali, Indonesia
}

\begin{abstract}
ABSTRAK
Penelitian ini bertujuan untuk mengetahui kinerja perusahaan dengan menggunakan metode Balanced Scorecard yang meliputi pengukuran kinerja dari perspektif; keuangan, pelanggan, proses bisnis internal, dan pembelajaran dan pertumbuhan. Penelitian ini menggunakan pendekatan deskriptif kualitatif dengan pengumpulan data yang bersumber dari data primer yaitu dengan melakukan wawancara dan kuesioner dan data sekunder yaitu dengan mengumpulkan data-data yang sudah ada. Kinerja perusahaan dengan Balanced Scorecard pada periode tahun 2015 dan 2016 menghasilkan bahwa secara keseluruhan kinerja perusahaan sudah baik. Hasil dari penelitian ini mendukung teori kinerja yang menjelaskan bahwa kinerja dapat dijadikan sebagai tolak ukur untuk mengetahui keberhasilan strategi perusahaan. Penggunaan metode Balanced Scorecard dalam mengukur kinerja perusahaan menghasilkan gambaran kinerja perusahaan secara keuangan maupun non keuangan sehingga metode pengukuran kinerja ini dapat diterapkan di perusahaan sebagai bahan pertimbangan manajemen untuk menyusun strategi yang akan digunakan untuk mencapai visi dan misi perusahaan.
\end{abstract}

Kata kunci: kinerja, pengukuran kinerja, balanced scorecard

\begin{abstract}
This study aims to determine the performance of companies using Balanced Scorecard method that includes performance measurement from the perspective; finance, customers, internal business processes, and learning and growth. This study used a qualitative descriptive approach with data collection sourced from the primary data that is by conducting interviews and questionnaires and secondary data is by collecting data that already exist. The company's performance with Balanced Scorecard in the period of 2015 and 2016 resulted in overall good performance of the company. The results of this study support the performance theory that explains that performance can serve as a benchmark to determine the success of corporate strategy. The use of Balanced Scorecard method in measuring the performance of the company produces a picture of the company's performance financially and non-finance so that this performance measurement method can be applied in the company as a consideration of management to develop strategies that will be used to achieve the vision and mission of the company.

Keywords: performance, performance measurement, balanced scorecard
\end{abstract}




\section{PENDAHULUAN}

Dewasa ini, perkembangan teknologi dan percepatan informasi memberikan dampak yang besar bagi keberlangsungan dunia bisnis. Perkembangan dan inovasi yang terus-menerus terjadi dalam pasar global menciptakan persaingan atau kompetisi antar perusahaan dalam dunia bisnis. Menurut Ellitan (2003), teknologi mendorong organisasi atau perusahaan dalam meningkatkan kinerja sehingga mencapai keunggulan kompetitif. Keunggulan kompetitif berkaitan dengan usaha suatu organisasi untuk bersaing dan unggul dalam mencapai tujuan (Porter, 1985). Dengan memanfaatkan perkembangan teknologi yang ada, pelaku bisnis harus dapat menciptakan inovasi-inovasi dalam pemenuhan kebutuhan konsumen yang seiring berubah dengan perkembangan teknologi untuk mencapai keunggulan kompetitif.

Pada mengatasi perubahan-perubahan tersebut perusahaan perlu mempersiapkan diri untuk tetap bertahan di lingkungan persaingan bisnis secara global. Dengan memiliki strategi-strategi yang tepat, manajer juga perlu mengatur strategi-strategi itu sedemikian rupa untuk menyelamatkan perusahaan. Strategi pada dasarnya merupakan suatu teori tentang bagaimana mencapai sasaran perusahaan (Tunggal, 2002:2). Sebagai pusat sistem, strategi, berarti harus menjadi dasar dan referensi aktivitas organisasi, anggaran, sistem pengukuran kinerja, sistem insentif, program kerja harian, pegawai, dan lainnya (Yuwono et al, 2002:53). Manajer sebagai pengambil keputusan di perusahaan dalam hal ini berupaya untuk mempersiapkan dan mengelola strategi-strategi untuk tetap 
mempertahankan perusahaan dapat bersaing di persaingan global dengan cara mengkaji prinsip-prinsip yang selama ini digunakan dalam perusahaan.

Pengukuran kinerja perusahaan memegang peran penting dalam memastikan strategi perusahaan dapat berjalan sejalan dengan visi serta misi perusahaan. Pengukuran kinerja merupakan tindakan pengukuran yang dilakukan terhadap berbagai aktivitas dalam rantai nilai yang ada pada perusahaan. Hasil pengukuran tersebut kemudian digunakan sebagai umpan balik yang akanmemberikan informasi tentang prestasi pelaksanaan suatu rencana dan titik di mana perusahaan memerlukan penyesuaian-penyesuaian atas aktivitas perencanaan dan pengendalian (Yuwono et al., 2002:23).

Pada pengukuran kinerja perusahaan disarankan untuk menggunakan beragam ukuran kinerja yang terintegrasi. Penilaian kinerja yang hanya melihat pada satu aspek saja misalkan hanya menilai sisi profitabilitas tanpa menilai aspek non keuangan beresiko terabaikannya keuntungan jangka panjang. Selain itu pengukuran kinerja secara keseluruhan akan berguna untuk menggabungkan tujuan, sasaran, tingkat nilai perusahaan dan elemen pemangku kepentingan yang lebih luas (Lumpkins dan Dess,1996).

Sistem pengukuran kinerja perusahaan secara tradisional yang pada umumnya digunakan hanya untuk mengukur kinerja perusahaan pada sisi keuangannya saja masih belum memadai. Menurut Niven, Paul R., (2006) pengukuran kinerja yang hanya berdasarkan pada tolok ukur keuangan memiliki kelemahan diantaranya: 1) Pengukuran kinerja dengan hanya menggunakan pengukuran kinerja keuangan perusahaan mendorong manajer untuk mengambil 
Ida Ayu Putu Rika Maharani dan I.G.A.N Budiasih. Penerapan...

keputusan jangka pendek dengan mengorbankan kepentingan jangka panjang. 2) Kinerja keuangan hanya bertumpu pada kinerja masa lalu dan kurang mampu sepenuhnya untuk menuntun ke arah tujuan perusahaan.

Pengukuran kinerja yang hanya menitikberatkan pada kinerja keuangan memiliki kelemahan antara lain ketidakmampuan mengukur kinerja harta-harta yang tidak tampak (intangible assets) dan harta-harta intelektual (sumber daya manusia) perusahaan, serta pada pengukuran kinerja keuangan hanya mampu bercerita mengenai sedikit masa lalu perusahaan dan tidak mampu sepenuhnya menuntun perusahaan ke arah lebih baik (Kaplan dan Norton, 2000).

PT. Gde Kadek Brothers Layar Antarnusa (Bounty Cruises) merupakan Perusahaan yang bergerak pada bidang Wisata Bahari dengan armada utamanya MV. Bounty Cruises di Pelabuhan Benoa - Bali. Berdiri sejak tahun 1999, Perusahaan ini sampai sekarang masih mampu mempertahankan aset perusahaan dengan memperkerjakan 160 karyawan. Perusahaan ini melayani perjalanan wisata dari Pelabuhan Benoa menuju ke Nusa Lembongan dan Nusa Penida.

Pergerakan jumlah penumpang yang berangkat dari masing-masing pelabuhan di Provinsi Bali tahun 2016 terutama untuk pengangkutan penumpang di Nusa Penida mendapat peringkat kedua setelah Padang Bai yaitu sebanyak 647.755 penumpang naik di Nusa Penida tahun 2016. Jumlah penumpang naik di Nusa Penida tahun 2016 meningkat sebanyak 90.68\% dibandingkan dengan tahun 2015. Kemudian penumpang turun di Nusa Penida pada tahun 2016 adalah sebanyak 648.309 penumpang turun, meningkat 91,6\% dari tahun sebelumnya (Statistik Transportasi Udara dan Laut Prov. Bali, Th 2016). Dilihat dari 
pergerakan naik turun penumpang di perairan Nusa Penida seperti yang dilaporkan di atas, dapat disimpulkan bahwa kepulauan Nusa Penida menjadi primadona pariwisata sehingga terjadi peningkatan yang tinggi pada dua tahun terakhir.

Meningkatnya daya tarik wisata di kepulauan Nusa Penida menjadi peluang besar bagi PT. Gde Kadek Brothers Layar Antarnusa (Bounty Cruises) untuk mempertahankan bisnisnya di bidang wisata bahari khususnya di perairan Nusa Penida. Namun menjamurnya usaha transportasi air di daerah pelabuhan Sanur menjadi saingan dan tantangan besar bagi Bounty Cruises. Tercatat bahwa sampai dengan Tahun 2016, terjadi peningkatan sebanyak 336.9\% total jumlah penumpang naik dari Pelabuhan Sanur jika dibandingkan dengan tahun 2015. Sedangkan untuk Pelabuhan Benoa menurun 10,39\% jumlah penumpang naik dibandingkan dengan tahun 2015 (Statistik Transportasi Udara dan Laut Prov. Bali, Th 2016). Turunnya nilai persentase penumpang naik di Pelabuhan Benoa dapat menjadi ancaman bagi pelaku bisnis di lingkungan Pelabuhan Benoa termasuk PT. Gde Kadek Brothers Layar Antarnusa (Bounty Cruises) sendiri.

PT. Gde Kadek Brothers Layar Antarnusa (Bounty Cruises) memberikan produk wisata Day Cruise yaitu perjalanan wisata air ke Nusa Lembongan dengan berbagai aktivitas air dan tour, wisata Dinner Cruise yaitu makan malam di atas kapal dengan pemandangan sunset dari perairan Benoa, dan Boat Transfer dari Pelabuhan Benoa - Nusa Lembongan - Pelabuhan Benoa. Perusahaan ini berorientasi pada pasar Overseas dengan rentang harga USD 30 - 119, dan untuk pasar domestik sendiri berkisar dari Rp 250.000,- s/d Rp 950.000,-. Rentang harga 
Ida Ayu Putu Rika Maharani dan I.G.A.N Budiasih. Penerapan...

yang dipatok oleh PT. Gde Kadek Brothers Layar Antarnusa (Bounty Cruises) lebih mahal dari harga yang dipatok oleh pengusaha boat-boat kecil di pesisir perairan sanur yang berkisar dari harga USD 20-50 untuk pasar Overseas dan Rp 130.000,- s/d Rp 350.000,- untuk pasar domestik. Adanya perbedaan harga tersebut tentu akan menimbulkan persaingan harga untuk pasar pelanggan yang lebih berorientasi pada harga yang murah.

Selain pada kondisi operasional di PT. Gde Kadek Brothers Layar Antarnusa (Bounty Cruises), perusahaan perlu menghindari adanya asimetri informasi akibat konflik kepentingan yang dapat terjadi antara pemilik dengan manajemen di perusahaan. Nugrahayu dan Retnadi (2015) menyatakan bahwa kinerja dapat dijadikan sebagai tolak ukur dalam mengetahui keberhasilan strategi perusahaan dan dapat memperlihatkan kontribusi para manajer terhadap perusahaan serta menjadi sumber informasi dalam mengevaluasi tindakan manajer.

Pada saat ini perusahaan belum memiliki cara yang tepat dalam mengimplementasikan strateginya ke dalam seluruh perangkat organisasi perusahaan. Terpakunya perusahaan pada pengukuran kinerja perusahaan secara tradisional dengan hanya melihat kinerja dari segi keuangannya saja tanpa melihat aspek non keuangan membuat perusahaan hanya dapat menyusun strategi untuk jangka pendek saja. PT. Gde Kadek Brothers Layar Antarnusa (Bounty Cruises) sampai saat ini menerapkan pengukuran kinerja dari segi keuangan saja dan belum memiliki acuan pengukuran yang baku untuk dapat melihat kinerja perusahaan dari aspek non keuangan. Dampaknya belum ada pengukuran yang 
pasti tentang pengembangan dan pelatihan karyawan, kepuasan pelanggan terhadap jasa yang diberikan, sehingga kemampuan perusahaan dalam pemenuhan kebutuhan pelanggan untuk jangka panjang masih belum dapat dilihat secara jelas. Hal ini tentu dapat berpengaruh pada perkembangan bisnis perusahaan

Berdasarkan pada kondisi-kondisi tersebut di atas maka adanya strategi perusahaan yang tepat merupakan hal yang penting dalam menjalankan operasional usaha untuk dapat bersaing dan tetap unggul di dunia bisnis. Perusahaan harus dapat mempertahankan keberadaannya dan mampu bertahan pada kondisi bisnis yang ada dengan cara mencari strategi-strategi baru dan sesuai dengan yang diperlukan perusahaan untuk dapat berjalan sesuai dengan visi dan misi perusahaan. Perusahaan perlu menilai bagaimana kinerja perusahaan yang dapat mewakili kondisi perusahaan secara keseluruhan sehingga perusahaan dapat menentukan strategi-strategi tepat yang digunakan untuk kelangsungan hidup bisnis perusahaan.

Balanced Scorecard (BSC) merupakan pendekatan yang dapat membantu perusahaan dalam menilai kinerja nyata perusahaan sehingga manajer dapat memberikan keputusan atau mengambil strategi-strategi yang tepat untuk mencapai target atau tujuan perusahaan (Khatoon \& Faroo1, 2014). Balanced Scorecard merupakan konsep manajemen yang dapat diterapkan pada organisasi bisnis yang menghasilkan produk maupun jasa. Pengukuran kinerja yang menitikberatkan pada aspek keuangan saja kurang mampu mengukur kinerja harta-harta tak nampak (intangible assets) dan harta-harta intelektual (sumber daya manusia) perusahaan (Mu'at, S. 2015). 
Ida Ayu Putu Rika Maharani dan I.G.A.N Budiasih. Penerapan...

Diperkenalkan oleh Robert Kaplan dan David Norton (1992) pada artikel pertamanya yang berjudul "The Balanced Scorecard Measure That Drive Performance” mengungkapkan dengan menilai kinerja perusahaannya melalui empat perspektif penting yaitu perspektif keuangan, perspektif pelanggan, perspektif proses bisnis internal, serta perspektif pembelajaran dan pertumbuhan.

Pada penelitian yang dilakukan oleh Kaplan dan Norton, ditemukan bahwa 54\% perusahaan yang diteliti menggunakan manajemen pelaksanaan strategi yang formal dimana $70 \%$ dari perusahaan tersebut memperoleh kinerja yang lebih baik jika dibandingkan dengan kelompok perusahaan yang sejenis (Poureisa, A. 2013). Balanced Scorecard dapat mendukung strategi perusahaan karena berfungsi sebagai penyeimbang antara perspektif keuangan dan nonkeuangan sehingga dengan demikian visi dan misi serta tujuan jangka panjang maupun jangka pendek perusahaan dapat tercapai (Ompi, P. dan Budiasih, I.G.A.N. 2015:47).

Pada mengukur kinerja yang keuangan dan non keuangan memerlukan pengukuran kinerja yang kompleks, hal ini bertujuan manajer dapat mengetahui strategi yang tepat yang dapat diterapkan pada perusahaan. Tanpa adanya penilaian kinerja yang kompleks, sulit untuk menilai apakah perusahan telah mencapai tujuannya dalam mengalami peningkatan kinerja dari segala aspek setiap tahunnya (Sukma, P. dan Krisnadewi. 2013:498). Pengukuran kinerja di PT. Gde Kadek Brothers Layar Antarnusa (Bounty Cruises) masih belum baku dan menggunakan metode tradisional dengan berbagai kelemahan, sehingga 
kurang maksimal dalam mendukung perencanaan manajemen dalam pengambilan keputusan.

Jensen dan Meckling (1976) pada artikel nya yang berjudul "Theory of the firm: Managerial behavior, agency cost and ownership structure" menjelaskan tentang hubungan antara pihak pemegang saham yang disebut dengan principal dan pihak yang diberikan otoritas oleh pemegang saham untuk menjalankan atau mengatur perusahaan yang disebut dengan agent. Manager sebagai agen menjalankan perusahaan berkewajiban untuk mengelola perusahaan sesuai dengan amanah dari prinsipal sebagai pemegang saham yaitu dengan meningkatkan nilai perusahaan, sebagai reward manajer atau agen akan mendapatkan bonus maupun kompensasi lainnya. Hubungan antara dua pihak ini dalam teori keagenan diikat dalam sebuah kontrak kerja. Kontrak kerja yang dimaksud adalah kontrak kerja antara pemegang modal dan manajer perusahaan, dimana antara agen dan prinsipal bertujuan memaksimalkan utility masing-masing dengan informasi yang dimiliki (Rahmah dan Sembiring,2014).

Kinerja merupakan gambaran mengenai suatu pencapaian dari program atau kegiatan pada suatu organisasi dalam mencapai sasaran yang dilakukan dengan perencanaan strategis. Menurut Mulyadi (2001:337), Kinerja merupakan suatu keberhasilan personil atau unit organisasi dalam mewujudkan sasaran strategik yang telah ditetapkan sebelumnya dengan perilaku yang diharapkan.

Kinerja biasanya digunakan untuk menyebutkan prestasi atau tingkat keberhasilan individu maupun kelompok individu. Kinerja dapat diketahui apabila individu ataupun kelompok individu memiliki kriteria keberhasilan yang telah 
ditetapkan. Kriteria keberhasilan tersebut berupa tujuan-tujuan atau target-target tertentu yang hendak dicapai (Mahsun, 2006).

Lohman (2003) menjelaskan bahwa pengukuran kinerja merupakan suatu aktivitas penilaian pencapaian target-target tertentu yang diderivasi dari tujuan strategis organisasi. Pengukuran kinerja dapat dilakukan dengan menggunakan system penilaian (ratting) yang relevan. Rating tersebut harus mudah digunakan sesuai dengan yang akan diukur, dan mencerminkan hal-hal yang memang menentukan kinerja (Werther dan Davis, 1996:346).

Sedangkan menurut Mulyadi dan Setiawan (1999) pengukuran kinerja merupakan salah satu instrument yang digunakan untuk mencapai tujuan yang diinginkan organisasi. Penilaian kinerja dapat digunakan untuk menekan perilaku yang tidak semestinya dan untuk merangsang serta menegakkan perilaku yang semestinya diinginkan, melalui umpan balik hasil kinerja pada waktunya serta pemberian penghargaan, baik yang bersifat intrinsik maupun ekstrinsik. Tujuan utama dari penilaian kinerja adalah untuk memotivasi individu atau kelompok individu dalam mencapai sasaran organisasi dan dalam memenuhi standar perilaku yang telah ditetapkan sebelumnya, sehingga membuahkan tindakan dan hasil yang diinginkan oleh organisasi.

Balanced Scorecard terdiri dari dua kata yaitu (1) kartu skor (Scorecard) dan (2) berimbang (Balanced). Balanced Scorecard merupakan kartu skor yang dimanfaatkan untuk mencatat skor hasil kinerja eksekutif. Melalui kartu skor, skor yang hendak diwujudkan eksekutif di masa depan dibandingkan dengan hasil kinerja sesungguhnya. Hasil perbandingan ini dimanfaatkan untuk menunjukkan 
bahwa kinerja eksekutif diukur secara berimbang dari dua perspektif; keuangan dan non keuangan, jangka pendek dan jangka panjang, intern dan ekstern. Oleh karena eksekutif akan dinilai kinerja mereka berdasarkan kartu skor yang dirumuskan secara berimbang, eksekutif diharapkan akan memusatkan perhatian dan usaha mereka pada ukuran kinerja non keuangan dan ukuran jangka panjang. (Mulyadi, 2007:3).

Menurut Pratiwi (2010) Balanced Scorecard mengembangkan seperangkat tujuan unit bisnis melampaui rangkuman ukuran finansial. Balanced Scorecard menekankan bahwa semua ukuran finansial dan non-finansial harus menjadi bagian sistem informasi untuk para pekerja di semua tingkat perusahaan. Balanced Scorecard menyatakan adanya keseimbangan antara berbagai ukuran eksternal para pemegang saham dan pelanggan, dengan berbagai ukuran internal proses binsis penting, inovasi, serta pembelajaran dan pertumbuhan.

Nugrahayu dan Retnadi (2015), pada karya ilmiahnya yang berjudul Penerapan Metode Balanced Scorecard sebagai Tolok Ukur Pengukuran Kinerja PT Glory Indonesia Abadi. Pada penelitian ini disebutkan bahwa PT Glory Indonesia Abadi hanya mengukur kinerjanya dengan perspektif keuangannya saja, sehingga kinerja perusahaan secara keseluruhan belum pernah dilakukan pengukuran. Dengan menggunakan pendekatan Balanced Scorecard ditemukan bahwa secara menyeluruh dapat dikatakan baik, namun pada perspektif pelanggan yang diukur dengan kepuasan pelanggan ditemukan bahwa masih terdapat pelanggan yang kurang puas dengan kinerja PT Glory Indonesia Abadi yang ditunjukkan dengan adanya keluhan pelanggan sehingga dapat disarankan 
Ida Ayu Putu Rika Maharani dan I.G.A.N Budiasih. Penerapan...

oleh penulis untuk melakukan upaya perbaikan baik dari segi internal maupun eksternal.

Firdaus dan Mildawati (2014) meneliti kinerja Perusahaan PT Regulo Lintas Nusantara (Arus Liar Group) dengan pendekatan Balanced Scorecard. Hasil penelitian pada karya ilmiah tersebut menyimpulkan bahwa dari ke empat perspektif kinerja PT Regulo Lintas Nusantara (Arus Liar Group) dikatakan baik namun pada perspektif keuangan yang diukur melalui dua indikator yaitu Return On Investment (ROI) dan Profit margin of Sales belum dapat mewakili tolok ukur perspektif keuangan sehingga perlu adanya penambahan yaitu Sales Growth Rate.

Christina, Y (2013) pada penelitiannya tentang pengukuran kinerja perusahaan PT Adhi Karya (Persero) Tbk., dengan pendekatan Balanced Scorecard menemukan bahwa dari ke empat perspektif kinerja PT Adhi Karya (Persero) Tbk., disimpulkan semakin baik dari tahun 2010 ke tahun 2011 dan bahwa perusahaan telah melakukan tindakan-tindakan yang yang dapat menyempurnakan tujuan-tujuan strategis yang dimilik perusahaan. Penulis pun menyarankan agar PT Adhi Karya (Persero) Tbk., menggunakan metode Balanced Scorecard dalam mengukur kinerja perusahaan secara keseluruhan karena Balanced Scorecard dapat mendukung tercapainya 5 (lima) strategi yang dimiliki oleh PT Adhi Karya (Persero) Tbk.,

Mubarokah (2014) meneliti kinerja perusahaan PDAM Tirto Panguripan Kabupaten Kendal menggunakan metode Balanced Scorecard. Dari penelitian tersebut ditemukan bahwa perusahaan mengalami penurunan kemmapuan dalam menghasilkan laba bersih, sehingga perusahaan disarankan untuk meningkatkan 
strategi dalam peningkatan pendapatan dan menekan biaya untuk dapat menghasilkan laba yang lebih besar dari tahun ke tahun.

Satyawati, Endang (2006) meneliti kinerja Rumah Sakit Umum Daerah Indramayu dengan Pendekatan Balanced Scorecard ditemukan bahwa pada perspektif Pelanggan menunjukkan bahwa retensi pasien cendrung menurun dan akuisisi pasien meningkat, namun para pasien belum puas terhadap pelayanan yang diberikan oleh RSUD Indramayu sehingga manajemen RSUD Indramayu perlu mengambil penanganan cepat yang dapat meningkatkan kepuasan pelayanan.

\section{METODE PENELITIAN}

Lokasi penelitian ini dilakukan di PT. Gde Kadek Brothers Layar Antasnusa (Bounty Cruises) yang merupakan perusahaan yang bergerak pada bidang perusahaan wisata bahari beralamat di Jl. Wisata Tirta I Pelabuhan Benoa.Perusahaan ini dipilih karena merupakan salah satu Perusahaan Wisata Bahari yang telah berdiri sejak 1999 (17 tahun), merupakan Perusahaan keluarga yang dipimpin oleh Wirausahawan Bali (lokal).

Objek Penelitian adalah suatu sifat yang ditetapkan oleh peneliti untuk mempelajari dan kemudian memperoleh kesimpulan (Sugiyono, 2014:13). Objek pada penelitian ini adalah ukuran kinerja PT. Gde Kadek Brothers Layar Antarnusa (Bounty Cruises) dimana pengukuran kinerja tersebut diukur melalui 4 (empat) perspektif yakni; Perspektif Keuangan, Perspektif Pelanggan, Perspektif Bisnis Internal, dan Perspektif Pembelajaran dan Pertumbuhan. 
Ida Ayu Putu Rika Maharani dan I.G.A.N Budiasih. Penerapan...

Di dalam penelitian ini populasi yang digunakan adalah seluruh karyawan dan pelanggan PT. Gde Kadek Brothers Layar Antarnusa (Bounty Cruises) pada tahun 2015-2016. Sampel yang diambil adalah data karyawan dan pelanggan PT. Gde Kadek Brothers Layar Antarnusa (Bounty Cruises) tahun 2015-2016. Metode pengambilan sampel yang digunakan adalah Metode Proportionate Stratified Random Sampling. Jumlah sampel yang diambil untuk pelanggan, dan karyawan di PT. Gde Kadek Brothers Layar Antarnusa (Bounty Cryuises) menggunakan rumus Slovin.

Metode pengumpulan data yang digunakan dalam penelitian ini adalah metode angket (kuisioner) dan metode observasi nonpartisipatif. Metode Angket (Kuisioner) dalam penelitian ini digunakan untuk memperoleh informasi tentang hal-hal yang berkaitan dengan tingkat kepuasan pelanggan dan motivasi karyawan di PT. Gde Kadek Brothers Layar Antarnusa (Bounty Cruises).

Merupakan metode ilmiah untuk pencapaian validitas yang tinggi reabilitasnya dan mempunyai peluang kebenaran ilmiah yang tinggi, sifat kuantitatif memberikan bobot (rating), peringkat (rangking), atau skor (Mulyana, 2005).Metode ini digunakan untuk pengukuran kinerja dengan menggunakan rasio-rasio pengukuran kinerja pada perspektif keuangan seperti pengukuran ROI, Profit Margin, dan Operating Ratio.

\section{HASIL PENELITIAN DAN PEMBAHASAN}

ROI digunakan untuk mengukur kemampuan dari modal yang diinvestasikan dalam keseluruhan aktiva untuk menghasilkan laba bersih. Adapun hasil perhitungan Return on Investment (ROI) sebagai berikut: 
Tabel 1.

Hasil Perhitungan Return on Investment

\begin{tabular}{cccc}
\hline Tahun & $\begin{array}{c}\text { Laba Bersih Setelah } \\
\text { Pajak (Rp) }\end{array}$ & Jumlah Aset (Rp) & ROI (\%) \\
\hline 2015 & 10.330 .052 .362 & 136.155 .983 .757 & 7,59 \\
2016 & 14.918 .595 .447 & 138.838 .462 .398 & 10,75 \\
\hline Sumber: Data diolah, 2018 & &
\end{tabular}

Berdasarkan pada Tabel 1 di atas dapat dianalisa bahwa pada tahun 2015 setiap investasi sebesar Rp 100,- perusahaan menghasilkan laba sebesar Rp 7,59. Kemudian dari tahun 2015 sampai dengan tahun 2016 terdapat peningkatan Return On Investment (ROI) sebesar 3,16 \% dimana pada tahun 2016 ROI nya menjadi 10,75\% yang berarti bahwa setiap investasi sebesar Rp 100,- perusahaan menghasilkan laba bersih sebesar Rp 10,75. Naiknya persentase ROI searah dengan meningkatknya kemampuan perusahaan dalam menghasilkan laba dari investasi yang dimiliki (Wiagustini,Ni Luh Putu; 2014). Peningkatan persentase ROI tersebut diindikasikan oleh adanya peningkatan Laba Bersih (setelah pajak) dan Jumlah Aset usaha.

Profit margin digunakan untuk menilai besar kecilnya laba usaha dalam hubungannya dengan penjualan untuk mengetahui kemampuan perusahaan menghasilkan laba dilihat dari transaksi penjualan pada perusahaan. Adapun hasil perhitungan Profit Margin sebagai berikut:

Tabel 2.

Hasil Perhitungan Profit Margin

\begin{tabular}{cccc}
\hline Tahun & $\begin{array}{c}\text { Laba Bersih Setelah } \\
\text { Pajak (Rp) }\end{array}$ & $\begin{array}{c}\text { Pendapatan } \\
\text { Usaha (Rp) }\end{array}$ & Profit Margin (\%) \\
\hline 2015 & 10.330 .052 .362 & 76.992 .269 .989 & 13,42 \\
2016 & 14.918 .595 .447 & 78.062 .881 .925 & 19,11 \\
\hline
\end{tabular}


Dari perhitungan Profit Margin yang telah disajikan pada Tabel 2 di atas dapat dianalisis bahwa adanya peningkatan Profit Margin yang tinggi dari tahun 2015 ke tahun 2016. Pada tahun 2015 nilai Profit Margin sebesar 13,42 \% nilai tersebut menunjukkan bahwa setiap transaksi penjualan sebesar Rp 100,perusahaan dapat menghasilkan laba sebesar Rp 13,42., nilai ini kemudian meningkat menjadi $19,11 \%$ di tahun 2016, ini berarti perusahaan menghasilkan laba sebesar Rp 19,11 pada setiap transaksi sebesar Rp 100 di tahun 2016. Nilai tersebut menunjukkan bahwa kemampuan perusahaan dalam meningkatkanmargin laba meningkat. Dilihat dari adanya peningkatan Perusahaan dalam menghasilkan laba dari tahun 2015 ke tahun 2016 yang diiringi dengan peningkatan penjualan di tahun tersebut kemampuan perusahaan dalam menghasilkan laba di setiap transaksinya dapat dikatakan baik.

Operating ratio digunakan untuk mengukur nilai biaya operasional perusahaan yang diperlukan dalam setiap transaksi penjualan. Rasio ini mencerminkan tingkat efesiensi perusahaan sehingga rasio operasi yang tinggi menunjukkan keadaan yang kurang baik karena berarti penjualan yang terserap dalam biaya juga tinggi, dan yang tersedia untuk laba kecil. Adapun hasil perhitungan Operating Ratio sebagai berikut:

Tabel 3.

Hasil Perhitungan Operating Ratio

\begin{tabular}{cccc}
\hline Tahun & $\begin{array}{c}\text { Biaya Operasional } \\
\text { Perusahaan (Rp) }\end{array}$ & $\begin{array}{c}\text { Pendapatan } \\
\text { Usaha (Rp) }\end{array}$ & Operating Ratio (\%) \\
\hline 2015 & 50.426 .863 .636 & 76.992 .269 .989 & 65,50 \\
2016 & 54.784 .334 .198 & 78.062 .881 .925 & 70,18 \\
\hline
\end{tabular}

Sumber: Data diolah, 2018 
Berdasarkan pada Tabel 3 di atas dapat dilihat bahwa terjadi peningkatan Rasio Operasi dari tahun 2015 sampai dengan tahun 2016 sebesar 4,68 \%. Dari peningkatan tersebut dapat dianalisis bahwa terjadi peningkatan biaya operasi yang terjadi di setiap rupiah transaksi penjualan perusahaan dimana pada tahun 2015 sebesar 65,50\% yang berarti setiap Rp 100,- nilai penjualan memerlukan biaya operasi sebesar Rp 65,5., kemudian untuk tahun 2016 Operating Ratio meningkat menjadi 70,18 \% yang berarti bahwa biaya operasinya meningkat menjadi Rp 70,18., setiap transaksi penjualan sebesar Rp 100,. Dari penjelasan tersebut dapat dikatakan bahwa nilai transaksi penjualan di PT. Gde \& Kadek Brothers Layar Antarnusa (Bounty Cruises) memerlukan biaya operasi yang besar dan meningkat dari tahun 2015 sampai dengan tahun 2016.

Akuisisi Pelanggan yang dihitung di PT. Gde Kadek Brothers Layar Antarnusa (Bounty Cruises) adalah jumlah Perusahaan Agen Wisata yang sudah terdaftar menjalin kontrak dengan Bounty Cruises di tahun 2015 dan 2016 yang kemudian dibandingkan dengan jumlah Perusahaan Agen Wisata baru yang mampu dimenangkan oleh Bounty Cruises melalui perjanjian kerjasama atau kontrak. Berikut hasil perhitungan Customer Acquisition (Akuisisi Pelanggan) di PT. Gde \& Kadek Brothers Layar Antarnusa (Bounty Cruises):

Tabel 4.

Hasil Perhitungan Customer Acquisition

\begin{tabular}{cccc}
\hline Tahun & Agen (lama) & Agen (baru) & $\begin{array}{c}\text { Customer } \\
\text { Acquisition (\%) }\end{array}$ \\
\hline 2015 & 1.351 & 57 & 4,22 \\
2016 & 1.408 & 281 & 19,96 \\
\hline
\end{tabular}

Sumber: Data diolah, 2018. 
Ida Ayu Putu Rika Maharani dan I.G.A.N Budiasih. Penerapan...

Dari Tabel 4 dapat dilihat bahwa terdapat peningkatan Customer Acquisition di Perusahaan bahkan menambah Perusahaan Agen Wisata baru di tahun 2015 maupun 2016. Peningkatan yang signifikan terjadi di tahun 2016 dengan menambah sebanyak 281 Perusahaan Agen Wisata baru, sehingga dari tahun 2015 sampai dengan 2016 terjadi peningkatan Customer Acquisition sebesar 15,47 \%. Adanya peningkatan Customer Acquisition tersebut menunjukkan bahwa Bounty Cruises mampu memenangkan pasar atau agen baru dari tahun ke tahun sehingga Customer Acquisition-nya dapat dikatakan baik. Kondisi seperti ini harus dapat dipertahankan oleh Bounty Cruises untuk dapat tetap eksis di pasar bisnis terutama pasar Wisata Aktivitas Bahari.

Pada Perspektif Keuangan, pengukuran kinerja PT. Gde Kadek Brothers Layar Antarnusa (Bounty Cruises) dinilai dari 3 Rasio yaitu; Return On Investment (ROI), Profit Margin, dan Operating Ratio. Hasil penilaian dari ketiga Rasio yang diterapkan di PT. Gde Kadek Brothers Layar Antarnusa (Bounty Cruises) adalah hasil uji ROI yang dilakukan di PT. Gde Kadek Brothers Layar Antarnusa (Bounty Cruises) pada laporan keuangan di tahun 2015 dan tahun 2016 menunjukkan peningkatan ROI dari 7,59 \% menjadi 10,75\%. Peningkatan ROI tersebut menunjukkan bahwa adanya peningkatan kemampuan modal yang diinvestasikan di perusahaan dalam menghasilkan laba bersih.

Hasil uji Profit Margin yang dilakukan di PT. Gde Kadek Brothers Layar Antarnusa (Bounty Cruises) pada laporan keuangan di tahun 2015 dan tahun 2016 menunjukkan peningkatan Profit Margin dari 13,42 \% menjadi 19,11\%. 
Peningkatan Profit Margin tersebut menunjukkan bahwa adanya peningkatan laba bersih dari tahun 2015 ke tahun 2016.

Hasil uji Operating Ratio yang dilakukan di PT. Gde Kadek Brothers Layar Antarnusa (Bounty Cruises) pada laporan keuangan di tahun 2015 dan tahun 2016 menunjukkan peningkatan Operating Ratio dari $65,50 \%$ menjadi $70,18 \%$. Peningkatan Operating Ratio tersebut menunjukkan bahwa adanya peningkatan biaya operasional dari tahun 2015 ke tahun 2016.

Hasil uji Customer Retention (Retensi Pelanggan) yang dilakukan di PT. Gde Kadek Brothers Layar Antarnusa (Bounty Cruises) menunjukkan bahwa terdapat peningkatan Customer Retention (Retensi Pelanggan) di tahun 2015 dantahun 2016 yaitu dari 5.317,97\% menjadi 5.873,77\%. Persentase tersebut menunjukkan bahwa setiap 1 Perusahaan Agen Wisata mampu membawa tamu ke Bounty Cruises sebanyak 53 lebih orang di tahun 2015. Jumlah ini meningkat di tahun 2016, yaitu setiap 1 Perusahaan Agen Wisata mampu membawa tamu sejumlah 58 lebih orang berkunjung ke Bounty Cruises.Peningkatan tersebut menunjukkan bahwa adanya peningkatan kemampuan perusahaan dalam mempertahankan hubungan dengan pelanggan dari tahun 2015 ke tahun 2016.

Hasil uji Customer Acquisition (Akuisisi Pelanggan) yang dilakukan di PT. Gde Kadek Brothers Layar Antarnusa (Bounty Cruises) menunjukkan adanya peningkatan dari 4,22 \% menjadi 19,96\% dari tahun 2015 ke tahun 2016. Adanya peningkatan nilai Customer Acquisition tersebut disebabkan oleh meningkatnya jumlah Perusahaan Agen Wisata yang terdaftar kontrak dengan Bounty Cruises yang awalnya hanya 57 agen baru yang terdaftar selama tahun 2015 menjadi 281 
agen baru yang terdaftar di tahun 2016. Peningkatan ini berarti bahwa adanya peningkatan kemampuan perusahaan dalam menarik pelanggan baru dari tahun 2015 ke tahun 2016.

Hasil uji Customer Satisfaction (Kepuasan Pelanggan) yang dilakukan di PT. Gde Kadek Brothers Layar Antarnusa (Bounty Cruises) dengan menggunakan Kuesioner Kepuasan Pelanggan yang mengukur 3 variabel yaitu variabel Atribut Produk dan jasa dengan nilai kepuasan adalah 27,11 \% pelanggan sangat puas, $51,04 \%$ pelanggan puas, $21,53 \%$ pelanggan cukup puas, dan $0,32 \%$ pelanggan kurang puas. Hal tersebut berarti bahwa dari hasil penilaian kepuasan pelanggan, pelanggan merasa puas dengan pelayanan yang diberikan oleh perusahaan. Namun, perusahaan juga perlu memperhatikan adanya pelanggan yang merasa kurang puas dengan pelayanan dengan nilai kurang puas adalah $0,32 \%$. Selain itu perusahaan harus berusaha meningkatkan kualitas produk dan jasa untuk pelanggan agar pelanggan semakin puas dengan pelayanan yang diberikan perusahaan.

Variabel Citra (Images) Perusahaan menghasilkan nilai kepuasan adalah $35,80 \%$ pelanggan sangat puas, 55,29 \% pelanggan puas, 8,74 \% pelanggan cukup puas, 0,17 \% pelanggan kurang puas. Hasil penilaian tersebut berarti bahwa pelanggan merasa puas dengan citra perusahaan. Perusahaan perlu meningkatkan citra perusahaan agar pelanggan semakin puas dengan citra yang dimiliki perusahaan.

Variabel hubungan dengan Pelanggan menghasilkan nilai kepuasan pelanggan sebesar $23,02 \%$ pelanggan sangat puas, 56,04\% pelanggan puas, 
$20,81 \%$ pelanggan cukup puas, dan $0,13 \%$ pelanggan kurang puas. Hasil penilaian tersebut berarti bahwa pelanggan merasa puas terhadap Hubungan Perusahaan dengan Pelanggan.Namun, perusahaan perlu meningkatkan lagi hubungan yang baik dengan pelanggan sehingga dapat meningkatkan kepuasan pelanggan terhadap hubungan perusahaan dengan pelanggan.

Proses Inovasi yang dilakukan di PT. Gde Kadek Brothers Layar Antarnusa (Bounty Cruises) dilakukan oleh manajemen dengan melihat kebutuhan pelanggan dan upaya dalam peningkatan kualitas baik dari segi pelayanan maupun keamanan sehingga perusahaan dapat tetap eksis dalam persaingan pasar pariwisata secara khusus. Inovasi yang berhasil dilakukan di perusahaan ini adalah pembaharuan menu makanan dalam program Day Cruise maupun Dinner Cruise. Inovasi ini memberikan dampak yang positif terhadap peningkatan jumlah pelanggan baru (Customer Acquisition) yang meningkat dari tahun 2015 ke tahun 2016 sebesar 15,47\%. Selain pembaharuan menu makanan, PT. Gde Kadek Brothers Layar Antarnusa (Bounty Cruises) juga berinovasi dengan memberikan pelayanan ekstra kepada pelanggan berupa Bounty Cruises Charter yang diperuntukkan kepada pelanggan yang ingin menyewa Kapal Bounty Cruises dalam jangka waktu tertentu. Bounty Cruises Charter Event telah melayani beberapa Acara besar diantaranya; Dinner Cruises Bank Mandiri ke Lombok pada bulan April 2016, dan CSR HUT BUMN ke Labuhan Bajo - NTT bersama Ibu Rini Soemarno sebagai Menteri BUMN pada bulan Oktober 2016.

Proses Operasi yang dilakukan PT. Gde Kadek Brothers Layar Antarnusa (Bounty Cruises) selain menerapkan srategi integrasi dari masing-masing 
Departemen dalam susunan Organisasi yang bertanggung jawab dalam masingmasing tugasnya, Perusahaan ini juga menerapkan konsep kekeluargaan secara menyeluruh ke karyawan/ti Bounty Cruises dengan tetap disiplin terhadap peraturan dan tata tertib di lingkungan kerja perusahaan. Adanya perasaan kekeluargaan yang nyaman dalam hubungan interaksi kerja di perusahaan memberikan dampak kepada karyawan yang menjadi loyal dan memiliki perasaan empati dalam lingkungan kerja.Sehingga dapat menimbulkan kerjasama yang baik dari masing-masing Departemen dalam pelayanan jasa ke tamu. Hal tersebut berdampak pada hasil pengukuran kinerja kepuasan pelanggan yang menyatakan bahwa dalam Citra (Images) Perusahaan, pelanggan merasa puas dengan pelauanan jasa yang diberikan perusahaan.

Perspektif pembelajaran dan pertumbuhan

Pada perspektif Pembelajaran dan Pertumbuhan di PT. Gde Kadek Brothers Layar Antarnusa (Bounty Cruises) dilihat dari kapabilitas dan pelatihan karyawan yang dilakukan di perusahaan dan mengukur motivasi karyawan dengan kuesioner.

Dari hasil pengumpulan data kuesioner yang telah disebar untuk karyawan dan karyawati di PT. Gde Kadek Brothers Layar Antarnusa (Bounty Cruises) yang terbagi menjadi 4 (empat) kategori demografi responden yaitu diantaranya adalah Jenis Kelamin, Umur, Pendidikan Terakhir, dan Lama Bekerja di PT. Gde Kadek Brothers Layar Antarnusa. Dilihat dari Jenis Kelamin, 81,63 \% Responden Kuesioner karyawan adalah Laki-laki dan 18,37 \% adalah perempuan dari jumlah total responden, yang berarti bahwa sumber daya manusia yang ada di perusahaan 
sebagian besar adalah laki-laki. Hal tersebut disebabkan karena jenis usaha dari perusahaan sendiri adalah kebanyakan melibatkan fisik di lapangan seperti olah raga air dan transportasi laut sehingga lebih banyak karyawan laki-laki daripada karyawan wanita.

Dilihat dari Usia atau Umur, dapat dilihat bahwa sebagian besar karyawan dan karyawti Bounty Cruises berusia lebih dari 41 tahun dengan nilai persentase sebesar 40,82 \%. Hal tersebut berarti SDM di perusahaan kebanyakan terdiri dari SDM dengan usia umur yang sudah matang dengan lingkup pekerjaan lapangan yang memang memerlukan keahlian khusus yang berpengalaman.

Dari segi ukuran pendidikan terakhir, dapat dilihat responden kuesioner karyawan dibagi menjadi 4 (empat) kelompok tingkat pendidikan terakhir, sebagian besar karyawan dan karyawati Bounty Cruises berpendidikan terakhir SMA / Sederajat dengan persentase sebesar 43,88 \% dari total karyawan.Hal tersebut diindikasikan oleh lingkup pekerjaan di perusahaan yang berorientasi ke lapangan dan tidak terlalu banyak memerlukan tenaga yang berpendidikan di atas SMA/Sederajat. Selain itu, peneliti menemukan bahwa sebagian besar tenaga kerja di Bounty Cruises melakukan pelatihan keahlian yang diberikan oleh perusahaan maupun pelatihan di instansi lain dengan sertifikasi khusus.

Dari segi Lama Bekerja atau Masa Kerja, sebanyak 40,82 \% dari total responden karyawan bekerja paling lama 5 tahun, dan $59,12 \%$ responden telah bekerja lebih dari 5 tahun di Bounty Cruises. Nilai tersebut menunjukkan bahwa perputaran karyawan di perusahaan kecil, hal tersebut diindikasikan terjadi karena tingkat kepuasan karyawan di perusahaan baik sehingga sebagian besar tenaga 
Ida Ayu Putu Rika Maharani dan I.G.A.N Budiasih. Penerapan...

kerja di PT. Gde Kadek Brothers Layar Antarnusa merasa nyaman dan puas selama bekerja di perusahaan.

Berdasarkan kinerja perusahaan dalam perspektif Balanced Scorecard yakni Pembelajaran dan Pertumbuhan yang dinilai dari kepuasan karyawan melalui kuesioner yang telah disebar, kemampuan PT. Gde Kadek Brothers Layar Antarnusa (Bounty Cruises) dalam memberikan kepuasan bagi karyawannya dibagi menjadi 3 variabel yaitu; hasil uji Kepuasan Karyawan yang dilakukan di PT. Gde Kadek Brothers Layar Antarnusa (Bounty Cruises) dengan menggunakan Kuesioner Karyawan yang mengukur 3 variabel yaitu; Variabel Kapabilitas Karyawan dengan nilai kepuasan sebesar 8,89\% karyawan sangat puas, 50,37 \% karyawan puas, 34,7 \% karyawan cukup puas, 5,93\% karyawan kurang puas, dan $0,15 \%$ karyawan tidak puas. Nilai tersebut berarti bahwa karyawan merasa puas dengan kapabilitas karyawan yang diberikan oleh perusahaan, hal tersebut dapat dibuktikan dengan masa kerja karyawan yang sebagian besar lebih dari 10 tahun bekerja. Kemudian perusahaan selalu memberikan kesempatan pelatihan bagi tenaga kerja di perusahaan untuk meningkatkan kapabilitas dan kemampuan tenaga kerja dalam menguasai lingkup pekerjaan, namun perlu diperhatikan bahwa nilai kurang puas karyawan terhadap kapabilitas karyawan masih pada bobot 5,93 \% yang berarti ada karyawan atau tenaga kerja yang merasa kurang puas dengan kapabilitas karyawan yang diberikan perusahaan.

Kapabilitas Sistem Informasi menghasilkan nilai kepuasan karyawan sebesar 5,79 \% karyawan sangat puas, 46,31\% karyawan puas, 42,05\% cukup puas, 5,48 \% kurang puas, dan 0,37\% karyawan sangat tidak puas. Nilai tersebut 
berarti bahwa karyawan merasa puas dengan Kapabilitas. Sistem Informasi yang ada di Perusahaan. Hal tersebut berarti bahwa dalam segi sistem informasi untuk karyawan, perusahaan sudah mampu memberikan kepuasan kapabilitas karyawan dalam perolehan informasi di perusahaan. Namun perlu diperhatikan bahwa nilai kurang puas karyawan terhadap Kapabilitas Sistem Informasi masih ada dengan bobot 5,48 \% yang berarti bahwa ada karyawan atau tenaga kerja di perusahaan yang merasa kurang puas dengan kapabilitas sistem informasi di perusahaan. Motivasi, Pemberdayaan dan Keselarasan Karyawan menghasilkan nilai kepuasan karyawan sebesar 8,13\% karyawan sangat puas, 33,15 \% karyawan puas, 45,34 $\%$ karyawan cukup puas, 13,11 \% karyawan kurang puas, dan 0,27 \% karyawan sangat tidak puas. Nilai tersebut berarti bahwa karyawan merasa cukup puas dengan Motivasi, Pemberdayaan dan Keselarasan Karyawan yang diberikan Perusahaan PT. Gde Kadek Brothers Layar Antarnusa (Bounty Cruises) hal tersebut diindikasikan karena Perusahaan menerapkan pendekatan kekeluargaan yang diterapkan kepada seluruh tenaga kerja di Perusahaan sehingga karyawan merasa nyaman dengan suasana kerja karyawan sehingga dianggap cukup puas, namun adanya ketidaksesuaian gaji karyawan dengan lingkup pekerjaan yang diterima karyawan di perusahaan memberikan nilai yang kurang puas dari penilaian kepuasan di 2 variabel sebelumnya yang mana nilai cukup puas lebih besar dari bobot nilai puas dan sangat puas, dan terdapat bobot nilai sebesar 13,11\% untuk kategori kurang puas pada variabel ini. 


\section{SIMPULAN}

Berdasarkan dari hasil analisis data penerapan Balanced Scorecard sebagai pengukuran kinerja perusahaan PT. Gde Kadek Brothers Layar Antarnusa (Bounty Cruises) yang telah diukur menggunakan 4 perspektif yaitu Perspektif Keuangan, Perspektif Pelanggan, Perspektif Proses Bisnis Internal, dan Perspektif Pembelajaran dan Pertumbuhan, dapat ditarik kesimpulan bahwa dari hasil uji seluruh penilaian kinerja keuangan yang telah dilakukan di Perusahaan untuk tahun 2015 dan 2016, ROI (Return On Investment) meningkat yang berarti bahwa adanya peningkatan kemampuan perusahaan dalam menghasilkan laba bersih dari modal yang dimiliki atau diinvestasikan perusahaan, sehingga dapat disimpulkan bahwa ROI (Return On Investment) perusahaan baik. Kemudian untuk Profit Margin di Perusahaan juga mengalami peningkatan, yang menunjukan bahwa adanya peningkatan laba bersih dari tahun 2015 ke tahun 2016 sehingga dapat disimpulkan bahwa Protif Margin perusahaan adalah baik. Pengukuran Operating Ratio perusahaan yang mengalami peningkatan, yang menunjukkan bahwa adanya peningkatan biaya operasional dari jumlah pendapatan yang dihasilkan perusahaan. Dapat disimpulkan apabila dilihat dari peningkatan pendapatan yang terjadi, adanya peningkatan biaya operasional normalnya dapat terjadi karena perusahaan mengorbankan biaya operasional untuk meningkatkan pendapatan, namun jika dilihat dari segi efesiensi, kinerja perusahaan kurang baik karena timbulnya beban operasional yang tinggi dari tahun sebelumnya menandakan Perusahaan belum mampu meningkatkan efesiensi pemanfaatan sumber daya yang dimiliki untuk memangkas biaya operasional. 
Pengukuran kinerja perspektif pelanggan dengan menilai Customer Retention (Retensi Pelanggan), Customer Acquisition (Akuisisi Pelanggan), dan Kepuasan Pelanggan. Dari hasil uji seluruh variabel tersebut didapatkan hasil Customer Retention (Retensi Pelanggan) yang meningkat dari tahun 2015 ke tahun 2016, sehingga dapat disimpulkan bahwa Customer Retention (Retensi Pelanggan) baik. Kemudian untuk Customer Acquisition (Akuisisi Pelanggan) juga mengalami peningkatan karena perusahaan mampu menarik Agen baru untuk dikontrak dari tahun 2015 ke tahun 2016 sehingga dapat disimpulkan bahwa Customer Acquisition (Akuisisi Pelanggan) juga baik. Dan pada penilaian Kepuasan Pelanggan menggunakan Kuesioner yang disebar ke 96 Responden Pelanggan dapat disimpulkan bahwa pelanggan merasa puas dengan pelayanan di Perusahaan, namun masih ada beberapa pelanggan yang merasa kurang puas sehingga perusahaan perlu meningkatkan pelayanan agar dapat meningkatkan kepuasan pelanggan.

Pengukuran kinerja proses bisnis internal dengan mendeskripsikan Proses Inovasi dan Proses Operasi perusahaan. Dari pemaparan Proses Inovasi yang dimiliki perusahaan dapat disimpulkan baik karena perusahaan mampu memenuhi permintaan peningkatan pelayanan jasa maupun produk di perusahaan dengan penambahan program Pembaharuan Menu Makanan, Bounty Cruises Charter, dan Pembaharuan dan Perbaikan Sistem Booking Online via Website yang mengindikasikan terjadinya peningkatan pendapatan, retensi pelanggan, dan akuisisi pelanggan di perusahaan. Kemudian untuk Proses Operasi, selain menerapkan strategi integrasi dari masing-masing Departemen dalam susunan 
Ida Ayu Putu Rika Maharani dan I.G.A.N Budiasih. Penerapan...

Organisasinya, perusahaan juga menerapkan konsep kekeluargaan secara menyeluruh ke karyawan/ti di Perusahaan untuk menciptakan rasa nyaman dalam berinteraksi kerja di perusahaan sehingga dapat memberikan pelayanan yang ramah kepada pelanggan, rasa loyal kepada perusahaan, dan rasa harmonis di lingkungan kerja, sehingga dapat disimpulkan bahwa proses operasi perusahaan adalah baik.

Pengukuran kinerja pembelajaran dan pertumbuhan dengan mendeskripsikan karakteristik dan pelatihan karyawan dan menilai kepuasan karyawan terhadap kinerja Perusahaan. Dari hasil penilaian kapabilitas dan pelatihan karyawan dideskripsikan dari karakteristik responden penelitian kuesioner karyawan yang menunjukkan hasil bahwa perusahaan memiliki tenaga kerja atau SDM yang sesuai dengan lingkup pekerjaan, berpengalaman, dan perputaran (turnover) karyawan kecil, sehingga dapat dikatakan bahwa SDM yang dimiliki Perusahaan adalah baik. Hal tersebut sebanding dengan pelatihan karyawan yang rutin dilakukan perusahaan setiap tahunnya yaitu Latihan Keselamatan dengan jumlah peserta meningkat dari tahun 2015 ke tahun 2016, dan Latihan Kompetensi yang diperuntukkan bagi karyawan yang baru bergabung di perusahaan dan penambahan keahlian (skill) karyawan. Dari hasil penilaian kepuasan karyawan yang dilakukan dengan menyebar sebanyak 98 kuesioner kepuasan karyawan, secara keseluruhan dapat dikatakan baik namun perlu diperhatikan bahwa pada Variabel Motivasi, Pemberdayaan dan Keselarasan Karyawan terdapat bobot nilai sebesar $13,11 \%$ untuk kategori kurang puas, hal tersebut diindikasikan terjadi karena adanya ketidaksesuaian gaji karyawan 
dengan lingkup pekerjaan yang diterima karyawan di perusahaan sehingga perusahaan perlu mengkaji strategi untuk dapat menyesuaikan penerapan gaji karyawan.

Dari keseluruhan hasil uji penelitian yang telah dilakukan pada perusahaan PT. Gde Kadek Brothers Layar Antarnusa (Bounty Cruises) dengan metode Balanced Scorecard. Penelitian ini dapat mendukung teori kinerja yang sebelumnya telah dijelaskan bahwa kinerja dapat dijadikan sebagai tolak ukur untuk mengetahui keberhasilan strategi perusahaan.

Beberapa saran yang dapat diberikan berdasarkan hasil penelitian adalah perusahaan perlu meningkatkan efesiensi terutama pada biaya operasional dengan menekan beban operasional yang masih memungkinkan untuk dilakukan tanpa mengurangi kualitas pelayanan produk dan jasa yang ada di perusahaan sehingga tidak terjadi peningkatan biaya operasional yang signifikan dari tahun ke tahun.

Perusahaan perlu memperhatikan kesejahteraan karyawan dalam hal motivasi, pemberdayaan dan keselarasan karyawan terutama dalam hal penyesuaian penggajian karyawan dengan lingkup pekerjaan di perusahaan untuk menghindari ketidakpuasan karyawan yang dalam jangka panjang dapat berakibat pada kejenuhan dan penurunan motivasi karyawan dalam bekerja, sehingga dapat meningkatkan motivasi dan keselarasan karyawan sehingga karyawan dapat bekerja dengan lebih baik lagi memberikan pelayanan.

Perusahaan sebaiknya melakukan survei kepuasan pelanggan maupun karyawan dalam kurun waktu setahun sekali untuk dapat mengukur atau mengevaluasi kinerja perusahaan terkait kualitas pelayanan dan sumber daya 
Ida Ayu Putu Rika Maharani dan I.G.A.N Budiasih. Penerapan...

sehingga perusahaan dapat mengembangkan strategi yang baik untuk meningkatkan kualitas pelayanan produk maupun jasa.

Perusahaan sebaiknya melakukan studi banding dengan perusahaan sejenis untuk dapat melihat kekurangan dan ancaman yang kiranya dapat diprediksi sebagai ukuran banding perusahaan untuk melakukan inovasi dan kreatifitas yang baik dan tepat untuk meningkatkan kepuasan pelanggan dan pendapatan dalam waktu yang berkepanjangan.

Pada penelitian selanjutnya sebaiknya untuk melakukan pengukuran kinerja perusahaan perlu menambah metode penelitian selain dengan metode Balanced Scorecard, misalnya penambahan analisis SWOT untuk dapat memberikan pembanding dengan berbagai ukuran sehingga pengukuran kinerja perusahaan tidak hanya menggambarkan kinerja yang ada di perusahaan tapi juga dapat melihat ukuran peluang, ancaman dari luar dan kelebihan serta kelemahan dari dalam perusahaan sendiri.

\section{REFERENSI}

Badan Pusat Statistik Provinsi Bali. 2015. Statistik Transportasi Udara dan Laut Provinsi Bali 2014. Denpasar.

Christina, Yessy Ni Putu dan I Putu Sudana.2013.Penilaian Kinerja Pada PT. Adhi Karya dengan pendekatan Balanced Scorecard. E-Jurnal Akuntansi Universitas Udayana, 5 (3),hal:516-529.

Ellitan, Lena. 2003. Peran Sumber Daya dalam Meningkatkan Pengaruh Teknologi Terhadap Produktifitas. Jurnal Ekonomi Manajemen \& Kewirausahaan, 5 (2), hal: 155-170.

Firdaus, Dzulchis dan Titik Mildawati. 2014. Pengukuran Kinerja Perusahaan Menggunakan Metode Balanced Scorecard. Jurnal Ilmu \& Riset Akuntansi Sekolah Tinggi Ilmu Ekonomi Indonesia (STIESA) Surabaya, 3 (8). 
Kaplan, Robert S dan David P Norton. 2000, Balanced Scorecard : Menerapkan Strategi Menjadi Aksi, Erlangga:Jakarta

Kaplan, Robert S dan David P Norton. 1992. The Balanced Scorecard: Measures That Drive Performance. Harvard Business Press, Boston.

Kaplan, Robert S. 2012. The Balanced Scorecard: Comments on Balanced Scorecard Commentaries. Journal of Accounting and Organizational Change, 8 (4), hal:539-545.

Kaplan, Robert S., dan David P. Norton.2004. Strategy Maps: Converting Intangible Assets Into Tangible Outcomes. Academic Journal Article Research-Technology Management, Harvard Business School Press, Boston, MA, 47 (2).

Khatoon, Saira dan Farooq Ayesa. 2014. Balanced Scorecard: to Measure Organizational Performance: A Case Based Study.The International Journal Business \& Management Aligarh Muslim University, India, 2 (9), hal:106-113.

Lohman. 2003. Tersedia (Online) mohmahsun.blogspot.com/2011/04/indikatorkinerja.

Lumpkins, G.T., Dess, Gregory G. 1996. Clarifying the Enterpreneural Orientation Construct and Linking it to Performance. The Academy of Management Review, 21 (1), hal: 135-172.

Mahsun M. 2006. Pengukuran Kinerja Sektor Publik. Yogyakarta: Fakultas Ekonomi UGM

Mardiasmo. 2009. Akuntansi Sektor Publik. Yogyakarta: ANDI.

Mu'at, Susnaningsih. 2015. Analisis Penilaian Kinerja (Keuangan dan Non Keuangan) pada SPBU X Menggunakan Pendekatan Balanced Scorecard.Jurnal Ekonomi Universitas Islam Bandung.

Mubarokah, Tri Chusni. 2014. Pengukuran Kinerja Perusahaan Melalui Balanced Scorecard (Studi Kasus : PDAM Tirto Panguripan Kabupaten Kendal). Jurnal Ekonomi dan Bisnis, Universitas Dian Nuswantoro, Semarang.

Mulyadi dan Setyawan Jhony. 2000. Sistem Perencanaan dan Pengendalian Manajemen Edisi Ke-2. Jakarta: Salemba Empat

Mulyadi. 1997. Akuntansi Manajemen: Konsep, Manfaat dan Rekayasa. Edisi 8. STIE-YKPN. Yogyakarta 
Niven, R. Paul, 2006. Balanced Scorecard Step-by Step: Maximizing Performance and Maintaining Results. New York: John Wiley \& Sons, Inc.

Nugrahayu, Erika Ributari dan Endang Dwi Retnani. 2015. Penerapan Metode Balanced Scorecard Sebagai Tolok Ukur Pengukuran Kinerja Perusahaan. Jurnal Ilmu \& Riset Akuntansi Sekolah Tinggi Ilmu Ekonomi Indonesia (STIESA) Surabaya, 4 (10).

Ompi, Pingkan., I.G.A.N Budiasih. 2015. Analisis Perbandingan Kinerja Perusahaan Dengan Metode Balanced ScorecardI Pada Indosat dan XL. E-Jurnal Akuntansi Universitas Udayana, Bali, 10 (1), hal:31-46.

Porter, Michael E., Linde, Class Van Derr. 1995. Toward a New Conception of The Environment Competitiveness Relationship. The Journal of Economic Perspective, 9 (4), Hal:97-118.

Porter, N. E. 1985. Competitive Advantage: Creating and Sustaining Superior Performance. Free Press: New York.

Poureisa, Arman, Mohaddeseh Bolouki A.A, dan Ako Efteghar. 2013. Balanced Scorecard: A New Tool for Performance Evaluation. Interdisciplinary Journal of Contemporary Research in Business, Islamic Azad University, Iran. 5 (1), hal: 974-978.

Pratiwi, Umi. 2010. Balanced Scorecard dan Manajemen Strategik. Jurnal Manajemen dan Akuntansi Fakultas Ekonomi Universitas Soedirman, Vol.11 (2), hal:166-174.

Sugiyono. 2016. Metode Penelitian; Kuantitatif, Kualitatif, dan $R \& D$. Bandung:Alfabeta.

Sukma, Nyoman Pramesti dan Komang Ayu Krisnadewi. 2013. Penilaian Kinerja Berbasis Balanced Scorecard Pada Bank Utama. E-Jurnal Akuntansi Universitas Udayana, Bali, vol 5 (2), hal:497-515.

Tunggal, Widjaja. 2002. Memahami Konsep Balanced Scorecard. Jakarta: Harvarindo.

Werther, William B. dan Davis, Keith, 1996, Human Resource and Personnel Management, $5^{\text {th }}$ ed., McGraw-Hill, New York

Yuwono, Sony. Edy Sukarno, dan Muhammad Ichsan. 2002. Balanced Scorecard menuju Organisasi yang Berfokus pada Strategi. Jakarta: PT Gramedia Pustaka Utama. 